\title{
A Comparative Study of Shifts in English Translations of The Quran: A Case Study on "Yusuf" Chapter
}

\author{
Reza Rezvani \\ Yasouj University, İran \\ Peyman Nouraey \\ Payame Noor University, Iran
}

\section{Introduction}

During the history of Translation Studies (henceforth TS), numerous theorists have provided different models, procedures and theories of translation studies. A controversial aspect, however, goes to the methods and procedures applied in the translations of sacred texts such as The Quran or The Bible. The underlying reason for such debate might go back to the sensitivity of such texts. As an example, the French humanist Dolet was burned at the stake after being accused of blasphemy and condemned by the theological faculty of the Sorbonne University in 1546. The same happened to Tvndale and Wycliffe's works which were banned. Moreover, many other sad endings happened during the history of sacred text translation (as cited in Munday, 2008, p. 23).

The translation of the Quran has always been a sensitive and daunting issue in Islamic theology. One of the reasons is actually rooted in the fact that "an Arabic word can have a range of meanings depending on the context" (Pickthall, 1977, p.2). This is commonly recognized as one of the main features of Semitic languages such as Arabic and Hebrew, in contrast with Analytic ones such as English and Latin. In the modern theology of Islam, the translation of the Quran is mostly referred to as an "interpretation" (Ruthven, 2006, p.90), rather than a precise translation given that the translator is necessarily a human being. This might indicate why Pickthall (ibid., p.3) choose to call his translation "The 
Meaning of the Glorious Quran" rather than "The Quran”.

As comparative studies of sacred texts have always been the center of attention in different fields of study, the present case study aimed at investigating one of the issues in the realm of translational comparative studies. This was carried out through delving into the strategies taken while translating from Arabic into English using Catford's (1965) model of translation shift approach.

\section{Translation Shift Typology}

The available translations of The Quran have been studied and analyzed through several models of TS. The translation 'shift' model was introduced by Catford (1965) and remains one of the most comprehensive translational comparative models. The term shift goes back to those linguistic changes a translator has to make during the translation process. Catford (ibid.) pointed to two general types of shifts including 'level shift' and 'category shift'. The latter has some subcategories. These are introduced briefly as follows:

1. Level shift (henceforth LS): "expressed by grammar in one language and lexis in another" (Catford, 1965, p.141).

2. Class shift (henceforth CS): a shift from one part of speech to another.

3. Unit shift or rank shift (henceforth US): in Munday's (2008) "where the translation equivalence in the Target Language (henceforth TL) is at a different rank to the Source Language (henceforth SL). Rank here refers to the hierarchical linguistic unit of sentence, clause, group, word and morpheme" (p.61).

4. Structural shift (henceforth SS): according to Catford (as cited in Munday, 2008, p.61), "this is the most common form of the shifts which involves mostly a shift in grammatical structure."

5. Intersystem shift (henceforth IS): a shift that takes place when there is an approximately corresponding system between the SL and the TL, but is not applicable in the process of translation.

Chesterman considers the translation shift model to be a comparative model of translation. Furthermore, Chesterman (2009) believes that these types of models "show the translations in relation to other texts and are based on contrastive research" (2009, p. 7). Likewise, translation researchers and analysts have used the shift model to find out more about the relations existing between different languages. 


\section{Review of the Related Literature}

One of the most controversial issues in translation has been the notion of equivalence. While dealing with sacred texts such as The Bible or The Quran, a translator is expected to have full and systematic control over the renderings made. As Larson (1998, p.153) claims, there is "seldom a complete match between languages and that is why it is often necessary to translate one word in the source text by several words in the target text in order to provide the best meaning". She also sustains that there is a significant gap between the cultures of the people who are speaking different languages and as a result, it is the translator's job to make as many adjustments as necessary during the process of translation.

On the other hand, the frequency of the shifts occurring in the translation process sometimes matters and has a significant role in terms of the existing relation between two languages, as shifts are known to be the tools of achieving a better piece of translated text. In a study conducted by Komijani (2005), different parts of three English novels were selected and then compared with their corresponding Persian translations in order to locate the dynamism of the shifts and also to uncover the so-called process. The results showed that structural shifts $(\mathrm{f}=49 \%)$ achieved the most frequency in translations from English to Persian. Other shifts included unit shifts (or rank shifts), intra-system shifts, class shifts and level shifts with the frequency of 20, 15.1, 9.3 and 6.4 respectively.

In another study carried out by Akbari (2006), the researcher sought to investigate different types of structural shifts while translating children's literature from English to Persian with the aim of delving into the act of message transfer from the source text to the target audience. To do so, the researcher gathered empirical data based on the stylistic comparison of the source text and the target text sentences from ten children's literature publications. These shifts were categorized under three subcategories including 'addition and deletion', 'sentence-bound word order' and 'tense'. The results of her study showed that the most frequent structural shift used in the translation of such texts was 'sentence-bound word order'.

The term translation shift seems to have reached a high level of significance in nearly all areas in TS including the media. In Sangargir's study (2006), the shift strategies in the translation of movie subtitles from English to Persian were investigated. This study consisted of a thorough examination of several best seller films and a laborious survey of the collected samples after hours of transcription. In 
order to perform effective intra and inter-lingual subtitling, contrastive and comparative analyses were carried out among the sample subtitles gathered from five best-selling movies. As the results, the most frequently used shift types were listed as the means of achieving a translated text holding a higher level of readability.

When it comes to The Quran, many translations are available in several languages. But the question still remains as to what happens during the process of translation, making a piece of translated text seem better or worse. According to Raof (2001, p.12), while translating The Quran, the language and the cultural-bound linguistic and rhetorical features are simply "inimitable and unproduceable into other languages to a satisfactory level in order to make the equivalent effect". In fact, Raof (ibid.) claims that "the Quranic intricacies have no equivalents in the target language and represent unique examples of linguistic and cultural untranslatability"; and it is here that translation shifts are manifested during the translation process.

As a case in point, Salman (2010) studied different aspects of shifts in Quranic texts. The study began with a review of the tenses in English and Arabic, focusing on the present and the past tenses in particular. Moreover, this study gave a detailed description of the term 'translation shift', as first initiated by Catford (1965). Two types of translation shifts, level shifts and category shifts were revealed. In addition, the sub-types of each level of shifts were exposed, surveying three translations of The Quran including Ali's, Shakir's, and Pickthall's. The results indicated that the incidence of tense shift in Shakir's translation was greater than in the other two translations. Moreover, four types of translation shifts were listed in terms of their frequency in the three translations studied including 1) tense shift from past to present, 2) tense shift from present to future, 3) tense shift from present to past and 4) tense shift from past to future.

With insight from the aforementioned studies, one of the most problematic renderings is assumed to be the translation of The Quran into English. In Shunnaq's (1998, p.42) opinion "the Arab translators may find certain lexical items in Arabic that have no equivalences in English, because the concept they refer to does not exist in English." Thus, the application of this model can be beneficial to the translators in order to understand what procedures other translators have taken ensure better decision-making. 
The present study aimed to investigate the frequency of the shifts in translations from Arabic into English in the light Catford's (1965) shift model. Translation shifts might vary in number and nature. In line with the aforementioned discussions, the present study tends to find an answer to the following research question:

- Is there any statistically significant difference between the types and frequencies of shifts introduced by Catford (1965) in the seven translations of The Quran from Arabic into English?

\section{Method}

\subsection{Translation Samples}

Seven English translations from the first thirty verses of the Chapter 'Yusuf' in The Quran formed the translation samples needed for the present study. The list included Sarwar, Arberry, Irring, Pickthall, Saffarzade, Shakir and Yusef Ali's translations.

\subsection{Data Collection Procedures}

Each and every possible element within the aforementioned seven translations was compared to its corresponding original and carefully recorded in tables of the comparative data collection. Appendix 2 provides a sample of the collected data. In some cases, one translation possibly referred to two (or in some rare cases, even three) types of shifts at the same time. Thus, in order to collect the data more precisely, all of the possible cases were carefully accounted for.

\section{Results and Findings}

Initially, every shift was inserted into a graph (see Appendix 1.). The main merit of this graph was to provide a general overview of the shift frequencies. However, the total numbers of shifts are shown in Figure 1. In line with Salman's (2010) study on shifts in Quranic texts, it is important to note that Shakir's translation holds the highest number of shifts in the translation process.

With the general understanding of the data in Figure 1, Figure 2 provides the mean of each shift type in all the seven translations. Clearly, Unit shift and Level shift hold the highest means, compared to other three types of shifts applied while translating a text from Arabic into English. 


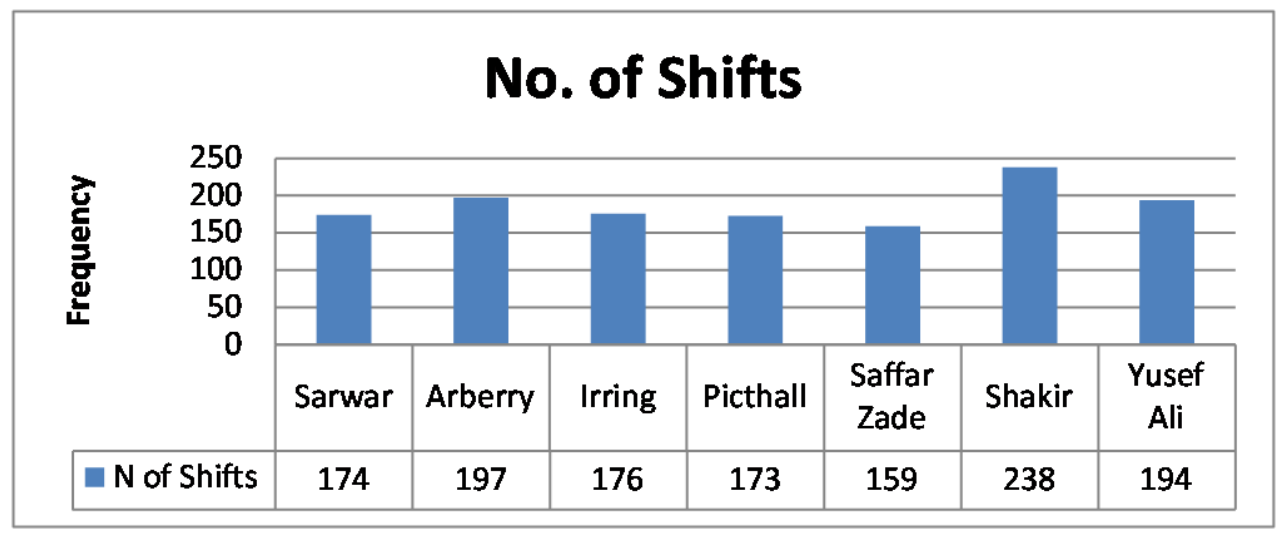

Figure 1. No. of Shifts in All Seven Translations

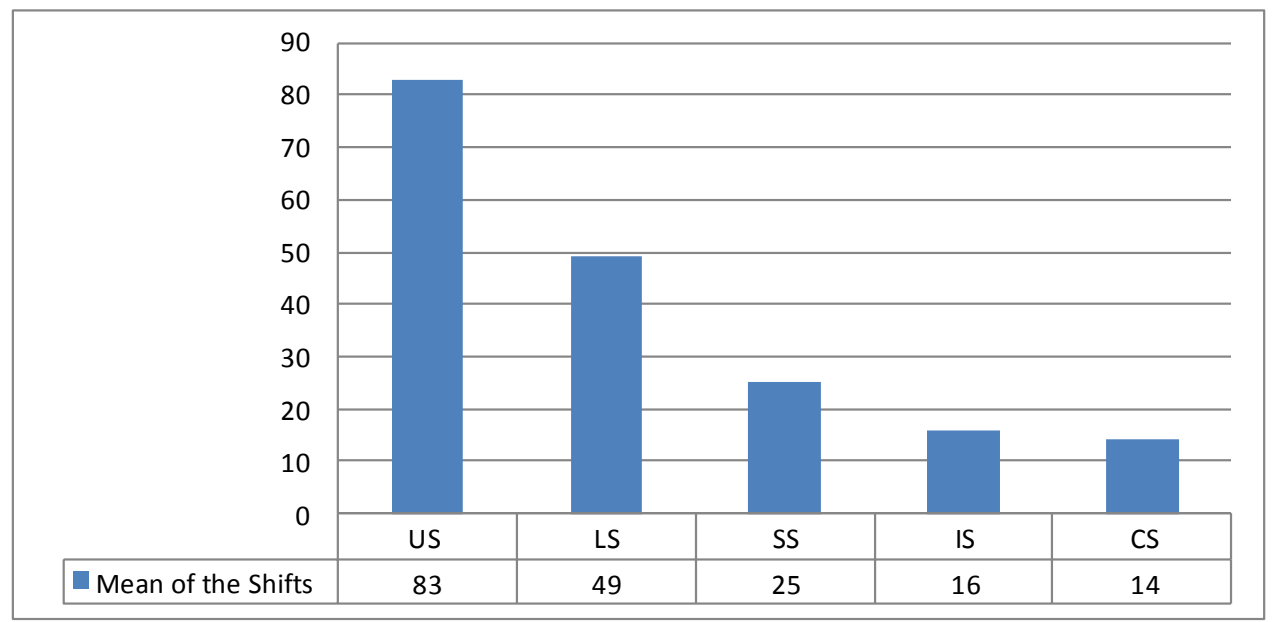

Figure 2.The Mean of Each translation Shift Type Within the Seven Translations Studied (Expected frequency $=37.4$ )

Concerning the main aim of the present study, the data are analyzed using the Chisquare procedure. As the residual sums between the groups of shifts and their expected frequencies $(=37.4)$ held a high level of difference, the test was expected to be statistically significant. The research question was then addressed using a Chi-Square test.

Table 1 illustrates the frequencies of different groups of translation shifts: 
Table 1. Frequencies of Different Groups of Translation Shifts

\begin{tabular}{cccc}
\hline Shift & Observed N & Expected N & Residual \\
\hline US & 83 & 37.4 & 45.6 \\
LS & 49 & 37.4 & 11.6 \\
IS & 16 & 37.4 & -21.4 \\
CS & 14 & 37.4 & -23.4 \\
SS & 25 & 37.4 & -12.4 \\
Total & 187 & & \\
\hline
\end{tabular}

With an understanding of Table 1, it is important to mention that US was the most frequent shift type detected. In contrast, CS held the lowest frequency. In order to search for the significance of all the five shift types, the Chi-square procedure was applied with the results presented in Table 2 .

Table 2. Chi-Square Test Statistics for Different Groups of Translation Shifts

\begin{tabular}{cc}
\hline & Mean Shift \\
\hline Chi-Square & $90.193^{\mathrm{a}}$ \\
df & 4 \\
Asymp. Sig. & .000 \\
\hline
\end{tabular}

Based on the results of the Chi-square test and the significance level observed (Asymp. Sig. $<0.05$ ), the differences indicated a statistical significance and thus it can be stated there was a significant difference between different types of shifts in the seven translations under investigation. The researchers then addressed the groups of shifts that held a statistically significant difference as compared to those that did not. To this end, different pairs of shifts were then compared with one another, using the Chi-square procedure. The first pair consisted in a comparison between US on the one hand, and LS on the other. Table 3 provides some basic descriptive information on this pair of shifts: 
Table 3. Frequencies of US vs. LS

\begin{tabular}{cccc} 
& Observed N & Expected N & Residual \\
\hline US & 83 & 66.0 & 17.0 \\
\hline LS & 49 & 66.0 & -17.0 \\
\hline
\end{tabular}

The differences between US and LS were tested through the Chi-square procedure, the results are shown in Table 4.:

Table 4. Chi-Square Test Statistics for US vs. LS

\begin{tabular}{cc}
\hline Chi-Square & US vs. LS \\
\hline df & $8.758^{\mathrm{a}}$ \\
Asymp. Sig. & 1 \\
\hline
\end{tabular}

As the results of the Chi-square tests in the two related tables above, a statistically significant difference between the frequencies of US and LS was revealed. The next pair of shifts included LS and SS. Table 5 presents the basic statistical information as related to these two shift types:

Table 5. Frequencies of LS vs. SS

\begin{tabular}{cccc} 
& Observed N & Expected N & Residual \\
\hline LS & 49 & 37.0 & 12.0 \\
\hline SS & 25 & 37.0 & -12.0 \\
\hline
\end{tabular}

Once more, using the Chi-square procedure, the differences between these two shift types was tested. Table 6 provides the results of this test: 
Table 6. Chi-Square Test Statistics for LS vs. SS

\begin{tabular}{cc}
\hline & LS vs. SS \\
\hline Chi-Square & $7.784^{\mathrm{a}}$ \\
df & 1 \\
Asymp. Sig. & .005 \\
\hline
\end{tabular}

As the results of the Chi-square test in the two tables revealed, there was also a statistically significant difference between the frequencies of LS as compared to SS. The following pair of shifts included SS and IS. Accordingly, Table 7 presents the basic descriptive information as related to this pair.

Table 7. Frequencies of SS vs. IS

\begin{tabular}{cccc} 
& Observed N & Expected N & Residual \\
\hline SS & 25 & 20.5 & 4.5 \\
IS & 16 & 20.5 & -4.5 \\
Total & 41 & & \\
\hline
\end{tabular}

In line with the methodology presented, the differences were retested through the Chi-square procedure. The results of this test are shown in Table 8, as follows:

Table 8. Chi-Square Test Statistics for SS vs. IS

\begin{tabular}{cc}
\hline \multicolumn{3}{c}{ SS vs. IS } \\
\hline Chi-Square & $1.976^{\mathrm{a}}$ \\
df & 1 \\
Asymp. Sig. & .160 \\
\hline
\end{tabular}

As the results of the Chi-square test in the two tables revealed, there were no statistically significant differences observed between the frequencies of SS as compared to IS. The last types of shifts were compared with one another. In this 
regard, Table 9 presents the basic descriptive data.

Table 9. Frequencies of SS vs. CS

\begin{tabular}{cccc} 
& Observed N & Expected N & Residual \\
\hline SS & 25 & 19.5 & 5.5 \\
CS & 14 & 19.5 & -5.5 \\
\hline
\end{tabular}

As the results of the Chi-square test show in Table 10, there were no statistically significant differences among the frequencies of these two types of shifts.

Table 10. Chi-Square Test Statistics for SS vs. CS

\section{SS vs. CS}

$\begin{array}{cc}\text { Chi-Square } & 3.103^{\mathrm{a}} \\ \text { df } & 1 \\ \text { Asymp. Sig. } & .078\end{array}$

\section{Discussion and Conclusion}

Based on the findings of the study, there was a statistically significant difference between US and LS, SS, IS and CS (i.e. all other groups of the shifts). This was true for all seven translations studied. In addition, there was a statistically significant difference between LS and SS, IS and CS in all seven translations studied. Moreover, the uses of the last three groups of shifts, namely SS, IS and CS held similar frequencies. Thus, there were not any statistically significant differences observed among these groups of shifts in all seven translations studied.

As mentioned before, the use of a shift has always been considered an inseparable element of a good and readable piece of translation. This could be due to the differences languages hold in nature (Yule, 1996). In other words these are the dynamics of languages; this phenomenon functions as a tool aimed at achieving a better piece of translated text. Finding the relationship between different languages 
could be of considerable assistance to linguists, translators, researchers, etc., working in the realm of TS and other related disciplines.

As the results of the present study revealed, the most frequently found shift types encountered in translating from Arabic into English were US and LS respectively. The other three shift types did not show any significant level of difference within the texts studied. Another important issue to be pointed out here is that nearly all of the seven translators whose works were studied had used these two top shift types with the highest frequencies in their translations.

Comparing the results of shift-bound investigations in different languages of the world provides the readers with further data, which often contrasts the results of the present study (see for example Komijani 2005). The need for collecting empirical data on the frequency and type of shifts in several translation contexts was previously highlighted. As translation shifts are known to act as the means to achieve a better translation, becoming familiar with their nature could be beneficial to the translation researchers, critics, etc. Thus, the results obtained from the present study are assumed to provide a better understanding of the act of translating from Arabic into English.

\section{References and notes:}

Akbari, M. (2006). Structural shifts in translation of children's literature

(Unpublishe master's thesis). Islamic Azad University, Science and Research Branch, Tehran.

Catford, J. C. (1965).A linguistic theory of translation. London: Oxford University Press. Chesterman, A. (2009). The name and nature of translation studies. Hermes - Journal of Language and Communication Studies, 42 (15), pp. 35-46.

Komijani, M. (2005). Shifts in English-Persian translation (Unpublishe master's thesis). Islamic Azad University, Science and Research Branch, Tehran.

Larson, M. L. (1998). Meaning-based translation: A guide to cross-language equivalence (2nd ed.). Lanham, New York and London: University Press of America.

Munday, J. (2008). Introducing translation studies: Theories and applications (2nd ed.). London: Routledge.

Pickthall, M. W. (1977). The meaning of the glorious Qur'an: Text and explanatory translation. New York: Muslim World League.

Raof, H. (2001). Qur'an translation: Discourse, texture and exegesis. Richmond: Curzon. Ruthven, M. (2006). Islam in the world (3rd ed.). London: Granta Books.

Salman, I. M. (2010).Tense shift in Quanic translation. Journal of the College of Arts, 54 (1), pp. 15-46.

Sangargir, M. (2006). Study of shift strategies in translation of movie subtitle from English to Persian (Unpublishe master's thesis). Tarbiat-e-Moalem University, Tehran.

Shunnaq, A. (1998). Problems in translating Arabic texts into English. In Abdullah Shannaq, Cay Dollerup, and Mohammed Saraireh (eds), Issues in translation. Irbid: 
Irbid National University \& Jordanian Translators' Association, pp.33-52.

Yule, G. (1996). The study of language (2nd ed.). Cambridge: Cambridge University Press.

\title{
SUMMARY
}

\section{A Comparative Study of Shifts in English Translations of The Quran: A Case Study on "Yusuf" Chapter}

\author{
Reza Rezvani \\ Yasouj University, İran \\ Peyman Nouraey \\ Payame Noor University, Iran
}

Long since Translation Studies emerged as a nascent academic discipline, it has seen a considerable number of descriptive theories and models, among which, Catford's (1965) translation 'shift' approach has garnered particular attention within the realm of translational comparative studies. Quranic texts have constantly been the center of attention, as the Quran has established itself as the most famous and sublime text in Arabic. As such, the present comparative study aimed at investigating the frequencies of different types of translation shifts occurring in translations form Arabic into English drawing on Catford's (1956) shift typology. To this end, seven translations of the first thirty verses of the Chapter 'Yusuf' rendered by Sarwar, Arberry, Irring, Pickthall, Saffarzade, Shakir and Yusef Ali were selected to be studied. First, each element was compared for any probable shift(s). Then, the Chi-square procedure was applied in order to establish the existence of any statistically significant differences in shift frequencies. The results indicated that there was a statistically significant difference between five types of shifts. The results also revealed that the most frequent translation shifts from Arabic into Persian were Unit shifts and Level shifts with a mean of 83 and 49 respectively.

Keywords: Translation shift, Yusuf, comparative translation studies, the Quran, Catford. 
Appendix 1. No. of Shifts in the Seven Translations Studied

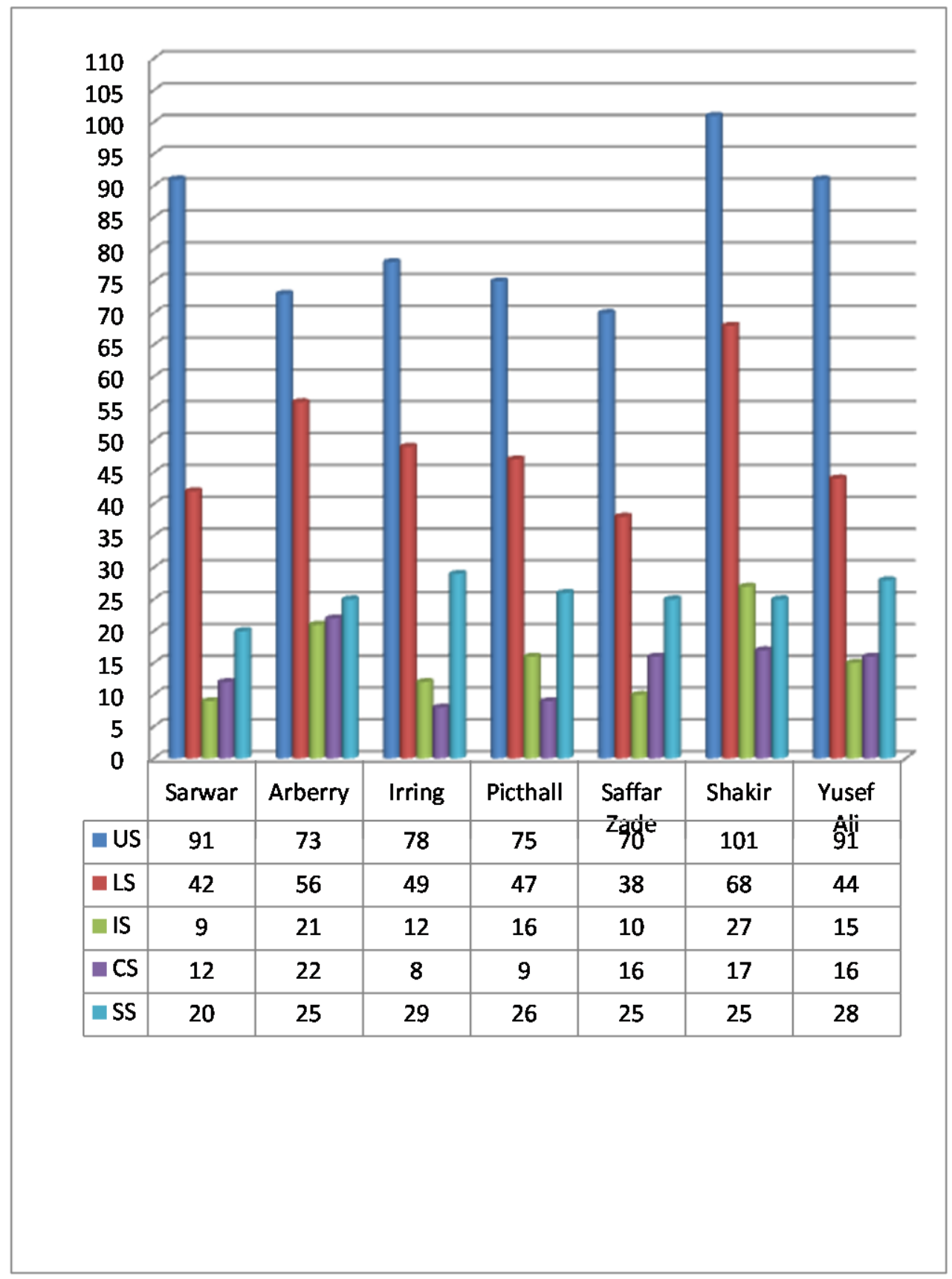


Appendix 2. Samples of the Shifts Occurred in the Seven Translations Studied

\begin{tabular}{|c|c|c|c|}
\hline Source Text & Target Text & SHIFT TYPE & Verse \\
\hline \multicolumn{4}{|c|}{ 1. Sarwar's Translation } \\
\hline يــوسف & The story of Joseph & US & 7 \\
\hline اخوتـه & His brothers & SS & 7 \\
\hline ايـت & There is evidence & LS & 7 \\
\hline ايـت & Evidence of the truth & US & 7 \\
\hline سـائـــــن & Those who seek to know & US & 7 \\
\hline قـالـو ا & Joseph's brother said to one another & LS & 8 \\
\hline J & There is no doubt that & US & 8 \\
\hline اخو & His brother & SS & 8 \\
\hline احب & Are more loved by & SS, US & 8 \\
\hline ابـيـنـا & Our father & SS & 8 \\
\hline و & Even though & CS & 8 \\
\hline نـحن & We are & LS & 8 \\
\hline عصبـه & All his offspring & US & 8 \\
\hline ابـانـا & $\mathrm{He}$ & CS & 8 \\
\hline ابــانـا & He is & LS & 8 \\
\hline ارضـاً & Somewhere far away from father & US & 9 \\
\hline يـخل & Shall we receive equal treatment & US & 9 \\
\hline مـن بـعـده & Thereafter & US, CS & 9 \\
\hline و & But & CS & 10 \\
\hline غيـبـت & A dark well & US & 10 \\
\hline يـــتقطه & Will take him away & US & 10 \\
\hline قـالـو ا & They asked & LS & 11 \\
\hline نــاصحون & Well wishes & US & 11 \\
\hline 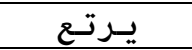 & Enjoy himself & US & 12 \\
\hline \multicolumn{4}{|c|}{ 2. Arberry's Translation } \\
\hline قــال & He said & LS & 13 \\
\hline لـيــخزنـنـى & It grieves me & US & 13 \\
\hline تـذهبـو & You should go & LS & 13 \\
\hline اخـاف & I fear & LS, US & 13 \\
\hline الـــــب & The wolf & IS, US & 13 \\
\hline 9 & While & CS & 13 \\
\hline انـتم & You are & LS & 13 \\
\hline قـالـو ا & They said & LS & 14 \\
\hline الــــــب & The wolf & IS & 14 \\
\hline عصبــ & A band & US & 14 \\
\hline انـا & We are & LS & 14 \\
\hline ذهبـو 1 & They went & LS & 15 \\
\hline غيـبـت & The bottom of & US & 15 \\
\hline الـجب & The well & IS, US & 15 \\
\hline اوحيـنـا & We have revealed & SS & 15 \\
\hline
\end{tabular}




\begin{tabular}{|c|c|c|c|}
\hline لـتـنـبــــهم & Thou shalt tell them & US & 15 \\
\hline لا يـشعـرون & When they are unaware & US & 15 \\
\hline جـآ & They came & LS & 16 \\
\hline ابـا هم & Their father & SS & 16 \\
\hline عشـاء & In the evening & US & 16 \\
\hline يـبـكون & They were weeping & US, LS & 16 \\
\hline قـالـو ا & They said & LS & 17 \\
\hline يـا ابـانــا & Father & US & 17 \\
\hline نـستـبـق & Running races & CS & 17 \\
\hline مـتـعنـا & Our things & SS & 17 \\
\hline الـــــب & The wolf & IS, US & 17 \\
\hline صدقـــن & Truly & CS & 17 \\
\hline جـآ \&و & They brought & LS & 18 \\
\hline قـمـيـصـا & His shirt & SS & 18 \\
\hline قــال & He said & LS & 18 \\
\hline انـفـسكم & Your spirits & SS & 18 \\
\hline امـر اً & To do somewhat & US & 18 \\
\hline تـصفــون & You describe & LS & 18 \\
\hline \multicolumn{4}{|c|}{ 3. Irring's Translation } \\
\hline و اردهم & Their water boy & SS, US & 19 \\
\hline يـبـشرى & What a godsend & US & 19 \\
\hline هذ ا & This is & LS & 19 \\
\hline غلم & A boy & US & 19 \\
\hline اسرو اس اسرو & They hid him & LS, US & 19 \\
\hline بـضعـا & A piece of merchandise & US & 19 \\
\hline يـعلمـون & They were doing & LS, US & 19 \\
\hline ثـمن & A trifling price & US & 20 \\
\hline مـعـدود 0 & Just a few & US & 20 \\
\hline الـز ا هـديـن & Quite indifferent & US & 20 \\
\hline اشـتـرئسه & Who bought him & US & 21 \\
\hline امـر اتـه & His wife & SS & 21 \\
\hline اكرمسى & Let be dignified & US & 21 \\
\hline مـثــونسـه & His stay & SS & 21 \\
\hline ولـد أ & As a son & IS, US & 21 \\
\hline تــاويـل & To interpret & US & 21 \\
\hline بـــغ اشده & He became of age & LS, US & 22 \\
\hline الـمـحسنـيـن & Those who act kindly & US & 22 \\
\hline رودتــ & Wanted to seduce him & US & 23 \\
\hline غلـقـت & She bolted & LS & 23 \\
\hline هيـت & Come here & US & 23 \\
\hline مـعـاذ الله & God protect me & SS & 23 \\
\hline ربسى & my lord & SS & 23 \\
\hline احسن & the best shelter & US & 23 \\
\hline مـثـو اى & to hold on by & US & 23 \\
\hline
\end{tabular}




\begin{tabular}{|c|c|c|c|}
\hline بـر هن & A proof & US & 24 \\
\hline ربسـ & His lord & SS & 24 \\
\hline الـفـحشـا & Sexual misconduct & US & 24 \\
\hline عبـا دنــا & Our servants & SS & 24 \\
\hline \multicolumn{4}{|c|}{ 4. Pickthall's Translation } \\
\hline استـبـــا & They raced with one another & LS, US & 25 \\
\hline ق ق قـدت & She tore & LS & 25 \\
\hline الـفـيـا & They met & LS & 25 \\
\hline سيـد هـا & Her Lord & SS & 25 \\
\hline L & What shall be & LS, US & 25 \\
\hline جز اء & His reward & US & 25 \\
\hline ا هـلك & Thy folk & SS & 25 \\
\hline 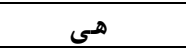 & She it was & LS, US & 26 \\
\hline رود دتـنى & Who asked of me & US & 26 \\
\hline شـا هـد & A witness & IS & 26 \\
\hline اهـلـيـمـا & Her own folk & SS, US & 26 \\
\hline صدقـت & She speaks truth & LS, US & 26 \\
\hline كـذبـت & She hath lied & LS, US & 27 \\
\hline هو & $\mathrm{He}$ is & LS & 27 \\
\hline الـصديـقــــن & The truthful & IS, CS & 27 \\
\hline $1 \leq 3$ & He saw & LS & 28 \\
\hline انسه & This is & LS & 28 \\
\hline كيـدكن & The guile of you women & US & 28 \\
\hline عظيم & Is very great & LS, US & 29 \\
\hline اســـفـرى & Ask forgiveness for & US & 29 \\
\hline ذنـبـك & Thy sin & SS & 29 \\
\hline كـنت & Thou are & SS & 29 \\
\hline الـخـاطنـــن & The faulty & IS, CS & 30 \\
\hline المــر اءيـز ت & The ruler's wife & IS, SS & 30 \\
\hline فـتـــــــا & Her slave-boy & SS & 30 \\
\hline شغفـها & He has smitten her & LS, US & 30 \\
\hline حبـاً & To the heart & US & 30 \\
\hline \multicolumn{4}{|c|}{ 5. Saffarzade's Translation } \\
\hline امـر ات & The wife of & US & 30 \\
\hline فـتــــها & Her slave-boy & SS & 31 \\
\hline شغفــا & She has affected her & LS, US & 32 \\
\hline ظللِ مـبـيـنِ & An obvious error & IS & 35 \\
\hline \multicolumn{4}{|c|}{ 6. $\quad$ Shakir's Translation } \\
\hline سمعت & she heard of & LS, US & 31 \\
\hline مـكر هن & their sly talk & SS, US & 31 \\
\hline اخـرج & come forth & US & 31 \\
\hline رأيـنـه & they saw him & LS, US & 31 \\
\hline اكـبـرنــه & they deemed him great & LS, US & 31 \\
\hline
\end{tabular}




\begin{tabular}{|c|c|c|c|}
\hline حش لله & remote is Allah & LS & 31 \\
\hline بـشر أ & a mortal & IS & 31 \\
\hline سمـعت & she heard of & LS, US & 31 \\
\hline مـكر هن & the sly talks & SS, US & 31 \\
\hline مـتكـاً & a party & IS, US & 31 \\
\hline اخرج & come out & US & 31 \\
\hline ر ايـنـه & they saw him & LS, US & 31 \\
\hline اكـبـرنــه & they did praise him & LS, US & 31 \\
\hline حش الله & Allah forbid & SS & 31 \\
\hline بـشر أ & a mortal human being & IS, US & 31 \\
\hline لـمـتـنـنـى & you blamed her & LS, US & 32 \\
\hline رودتـه & I asked him an evil act & LS, US & 32 \\
\hline اسقـصم & he refused & LS, US & 32 \\
\hline لـيـسجنـن & he shall be imprisoned & LS, US & 32 \\
\hline الـصفـريـن & the humiliated ones & IS, US & 32 \\
\hline قـال & Yusuf prayed to Allah & LS, US & 33 \\
\hline احب & is dearer & LS & 33 \\
\hline يـــــــى & they call me & LS, US & 33 \\
\hline لا لــصرف & do not turn away & US & 33 \\
\hline الـجهـلـيـن & the ignorant ones & IS, US & 33 \\
\hline كيــد هن & their plot & SS, US & 34 \\
\hline الـعـلـيم & the knowing & IS, US & 35 \\
\hline بسد ا & they dedicated & LS, US & 35 \\
\hline راو & they had seen & LS, US & 35 \\
\hline الايـت & the symptoms of his innocence & IS, US & 35 \\
\hline لـيـسحبـتــه & they should imprison Yusuf & LS, US & 35 \\
\hline فـتــــان & two young men & US & 36 \\
\hline ارئـنــى & I dreamed & LS, US & 36 \\
\hline ا اعصر & I was pressing & LS, US & 36 \\
\hline احمل & I was carrying & LS, US & 36 \\
\hline الـمـحسنـيـن & the right men & IS, US & 36 \\
\hline \multicolumn{4}{|c|}{ 7. Yusef Ali's Translation } \\
\hline لـمـــــنـى & Ye did blame me & LS, US & 32 \\
\hline رودتـه & I did seek to seduce him & SS, US & 32 \\
\hline اسقـم & He did fairly save himself guiltless & LS, US & 32 \\
\hline امـر & My bidding & US & 32 \\
\hline ا يـسجنن & He shall certainly be cast in prison & US & 32 \\
\hline الـصغـريـن & The company of the vilest & US & 32 \\
\hline احب & Is dearer & LS & 33 \\
\hline يـــــونـنـى & They invite me & LS, US & 33 \\
\hline تــرف & Thou turn away & LS, US & 33 \\
\hline كيـد هن & Their snare & SS & 33 \\
\hline الـجهـليـن & The ignorant & IS, US & 33 \\
\hline ربــ & His lord & SS & 34 \\
\hline
\end{tabular}




\begin{tabular}{|c|c|c|c|}
\hline صرف & Turned away & LS, US & 34 \\
\hline الـسمـيـع & Hearth & CS & 34 \\
\hline الـعـلـيـم & Knoweth & CS & 34 \\
\hline بـد ا & It occurred & LS, US & 35 \\
\hline راو & They had seen & LS, US & 35 \\
\hline الايــات & The signs & IS & 35 \\
\hline حيـن & A time & IS & 35 \\
\hline فـتـــان & Two young men & US & 36 \\
\hline ارِــنــى & I see myself in a dream & LS, US & 36 \\
\hline ا & Pressing & CS & 36 \\
\hline احمل & Carrying & CS & 36 \\
\hline الـمـحسنـيـن & One that doth good & US & 36 \\
\hline
\end{tabular}

